\title{
Can resistant starch and/or aspirin prevent the development of colonic neoplasia? The Concerted Action Polyp Prevention (CAPP) 1 Study
}

\author{
John C. Mathers ${ }^{1 *}$, Ian Mickleburgh ${ }^{1}$, Pam C. Chapman ${ }^{2}$, D. Tim Bishop ${ }^{3}$ and John Burn ${ }^{2}$ \\ ${ }^{1}$ Human Nutrition Research Centre, School of Clinical Medical Sciences, University of Newcastle, \\ Newcastle upon Tyne NE1 7RU, UK \\ ${ }^{2}$ Institute of Human Genetics, University of Newcastle, Bioscience Centre, Times Square, Scotswood Road, \\ Newcastle upon Tyne NE1 4EP, UK \\ ${ }^{3}$ Genetic Epidemiology Division, Cancer Research UK, University of Leeds, Cancer Genetics Building, \\ St James's University Hospital, Leeds LS9 7TF, UK
}

\begin{abstract}
Loss of function of the adenomatous polyposis coli $(A P C)$ tumour suppressor gene through truncating mutations or other means is an early event in most colo-rectal cancer (CRC). The APC gene encodes a large multifunctional protein that plays key roles in several cellular processes, including the wnt signalling pathway where an intact APC protein is essential for down regulation of $\beta$-catenin. The APC protein also plays a role in regulation of cell proliferation, differentiation, apoptosis, cell-cell adhesion, cell migration and chromosomal stability during mitosis. Acquisition of a non-functional $A P C$ gene can occur by inheritance (in the disease familial adenomatous polyposis (FAP)) or by a sporadic event in a somatic cell. Whilst there is strong epidemiological evidence that variation in diet is a major determinant of variation in CRC incidence, conventional adenoma recurrence trials in sporadic cases of the disease have been relatively unsuccessful in identifying potentially protective food components. Since the genetic basis of CRC in FAP and in sporadic CRC is similar, intervention trials in FAP gene carriers provide an attractive strategy for investigation of potential chemo-preventive agents, since smaller numbers of subjects and shorter time frames are needed. The Concerted Action Polyp Prevention (CAPP) 1 Study is using a $2 \times 2$ factorial design to test the efficacy of resistant starch $(30 \mathrm{~g}$ raw potato starch-Hylon VII $(1: 1, \mathrm{w} / \mathrm{w}) / \mathrm{d})$ and aspirin $(600 \mathrm{mg} / \mathrm{d})$ in suppressing colo-rectal adenoma formation in young subjects with FAP. Biopsies of macroscopically-normal rectal mucosa are also being collected for assay of putative biomarkers of CRC risk.
\end{abstract}

\section{Adenomatous polyposis coli: Colo-rectal cancer: Familial adenomatous polyposis: resistant} starch: Asprin

\section{Genetic basis of colon cancer}

At its most fundamental, colo-rectal cancer (CRC) is a genetic disease due to loss of function of tumour suppressor genes and the activation of oncogenes. These genetic defects give the tumour cell competitive advantages (Hanahan \& Weinberg, 2000) including: ability to replicate faster and/or indefinitely; self-sufficiency in growth signals; reduced sensitivity to apoptotic signals; resistance to anoxia; ability to evade immunosurveillance. Tumour suppressor genes may be inactivated by mutations in, or chromosomal loss of, both alleles or by hypermethylation of the promoter region of the gene. The latter process is potentially reversible. This loss of function results in failure to regulate key cellular processes, including proliferation, apoptosis and differentiation. Oncogenes (derived from normal cellular genes known as proto-oncogenes) encode oncoproteins, which can transform cells to malignancy. Mutations result in the oncoprotein having a novel structure (and, therefore, function), being present where it is normally absent or being expressed at higher than normal levels. In the latter two cases the mutation results in altered transcriptional control.

Approximately 3-5\% of CRC cases have a known dominantly-inherited predisposition, another $5 \%$ of CRC 
families have highly-penetrant predisposing genes yet to be identified and in a further $5-10 \%$ there is a considerable family history (Burn et al. 2001) with $\geq 75 \%$ of cases being described as 'sporadic'. The best-characterised inherited predispositions to CRC are familial adenomatous polyposis (FAP) and hereditary non-polyposis colo-rectal cancer (HNPCC), but other rare syndromes include Juvenile polyposis, basal cell naevus syndrome (Gorlin's syndrome), Peutz-Jeghers syndrome and Turcot's syndrome (Burn et al. 2001). FAP is caused by germline mutations in the adenomatous polyposis coli (APC) gene (see p. 54), whilst hereditary non-polyposis HNPCC results from an inherited defect in one of the genes encoding the DNA mismatch repair system. From the perspective of CRC aetiology and prevention, the key finding is that the gene defects responsible for these relatively rare inherited syndromes are acquired in somatic cells and give rise to 'sporadic' CRC.

\section{Diet in the aetiology and prevention of colo-rectal cancer}

There is an approximately 15 -fold range in age-standardised incidence of CRC across the world and good epidemiological evidence that much of this variation can be attributed to variation in food intake patterns (Department of Health, 1998). However, it has proved rather difficult to identify which foods or food components, in what quantities and over what time periods, are protective and which confer increased risk. The UK Working Group on Diet and Cancer concluded that there 'is moderately consistent evidence that diets with less red and processed meat and with more vegetables and fibre are associated with lower risk of colo-rectal cancer. Evidence is inconsistent for vitamins A, C and E, and $\beta$-carotene.' (Department of Health, 1998). The strongest evidence for protection (or, indeed, adverse effect) comes from suitably designed intervention trials but there have not been, to our knowledge, any nutritional intervention trials in CRC in which cancer has been the endpoint. Most of the trials to date have used surrogate end points, including putative biomarkers of risk such as altered mucosal cell dynamics or histological changes such as adenoma recurrence. Several recent trials using adenoma recurrence as the primary end point have shown no benefits of increased dietary fibre intake alone (for systematic review, see Asano \& McLeod, 2002) or in combination with increases in intakes of fruit and vegetables and reduced fat intake (Schatzkin et al. 2000) despite the encouraging evidence from observational epidemiological studies (Department of Health, 1998). There appear to be no intervention studies with meat or meat products as the intervention agent. As only about one in ten adenomas in the large bowel will become a carcinoma and the factors that cause progression to carcinoma may be different from those that initiate polyp growth, it is possible that increased intakes of dietary fibre and other food components could prevent carcinoma development, with such benefits being difficult to detect in adenoma recurrence trials.

On the basis of the evidence that $A P C$ mutations are important in the early development of most CRC tumours (Powell et al. 1992) and that mutations in APC are causal for FAP, it is argued that FAP subjects are good models of $A P C$-driven carcinogenesis and would be good models for understanding the impact of exogenous materials (drugs and dietary agents) on tumour development in CRC.

\section{The adenomatous polyposis coli gene and its protein}

The APC gene located at chromosome $5 q 21$ was cloned in 1991 (Groden et al. 1991; Kinzler et al. 1991), spans an estimated $98 \mathrm{~kb}$ genomic DNA (Thliveris et al. 1996) and is normally composed of fifteen exons, which combine to give a coding sequence of $8972 \mathrm{bp}$. The most $3^{\prime}$ exon is unusually large at $7 \mathrm{~kb}$ (Fig. 1).

$A P C$ contains at least twenty-one exons, of which seventeen are presumed to be coding because they are downstream of an in-frame initiation codon (Santoro \& Groden, 1997). Several splice variants have been described, including those in the non-coding exons 1A and 1B (Horii et al. 1993) and in codon 9 (Groden et al. 1991) and Sulekova \& Ballhausen (1995) reported a novel coding exon of $54 \mathrm{bp}$ between exons 10 and 11 . The proteins encoded by alternatively-spliced variants of $A P C$ have been detected in neural tissue (Pyles et al. 1998), and other tissue specific variants are probable. A brain-specific $A P C$ homologue (designated $A P C L$ ) has been located on chromosome 19p13.3, which appears to have similar functions to APC in that particular tissue (Nakagawa et al. 1998).

The $A P C$ gene encodes a 2843 -amino acid protein with a molecular mass of approximately $310 \mathrm{kDa}$ (Groden et al. 1991). This large protein includes several structural and functional domains (see Fig. 2), through which the APC protein interacts with other cellular proteins.

Domains at the $\mathrm{NH}_{2}$ terminal of the protein include the coiled-coil region, which mediates homo-oligomerisation. Probably the most intensively studied domains are the three fifteen amino acid repeats (between amino acids 1020 and 1169) and the seven twenty amino acid repeats (between amino acids 1262 and 2033), which are responsible for binding ( $\mathrm{Su}$ et al. 1993) and down regulation (Rubinfeld et al. 1997) respectively of $\beta$-catenin, the key role played by APC in the wnt signal transduction pathway (described p. 52). APC is found in the cytoplasm of the cell, where it interacts with axin via its seven armadillo repeats (a fortytwo-amino acid repeated structural motif; Kinzler et al. 1991) and its three Ser-Ala-Met-Pro repeat motifs (Kishida et al. 1998).

\section{Functions of the adenomatous polyposis coli protein}

The APC protein is best known as a tumour suppressor in the human colon, a property due, apparently, to the key role played by APC in destabilization or down regulation of $\beta$ catenin in the wnt signalling pathway (Fig. 3).

In the absence of wnt several proteins, including APC, form a multi-protein complex, which results in degradation of $\beta$-catenin. When the wnt receptor known as 'frizzled' binds a wnt signal peptide, a cascade is initiated, which prevents $\beta$-catenin degradation through the ubiquitinproteasome pathway (Klingensmith \& Nusse, 1994). The key step in the pathway is believed to be binding of glycogen synthase kinase $3 \beta$ by the second messenger protein 'dishevelled', so preventing it from phosphorylating $\beta$-catenin, which is degraded only after phosphorylation. 


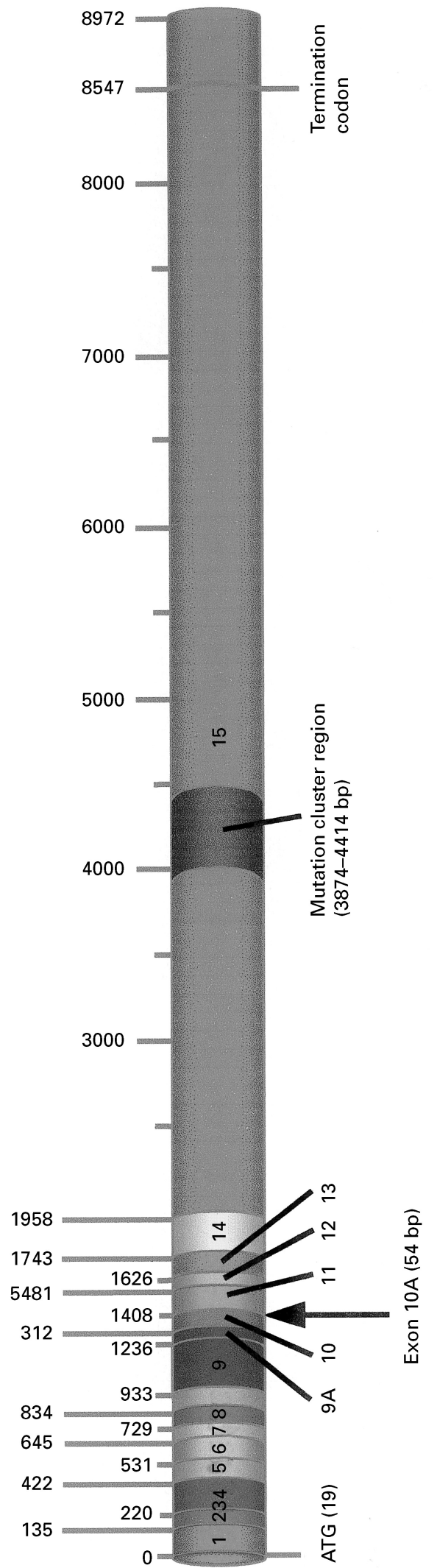

Fig. 1. Exon structure of the adenomatous polyposis coli gene. Numbers shown above the exon structure are exon boundaries in base pairs. The initiation (ATG (19)) and termination codons are indicated. Note also the mutation cluster region which is important in sporadic truncating mutations.

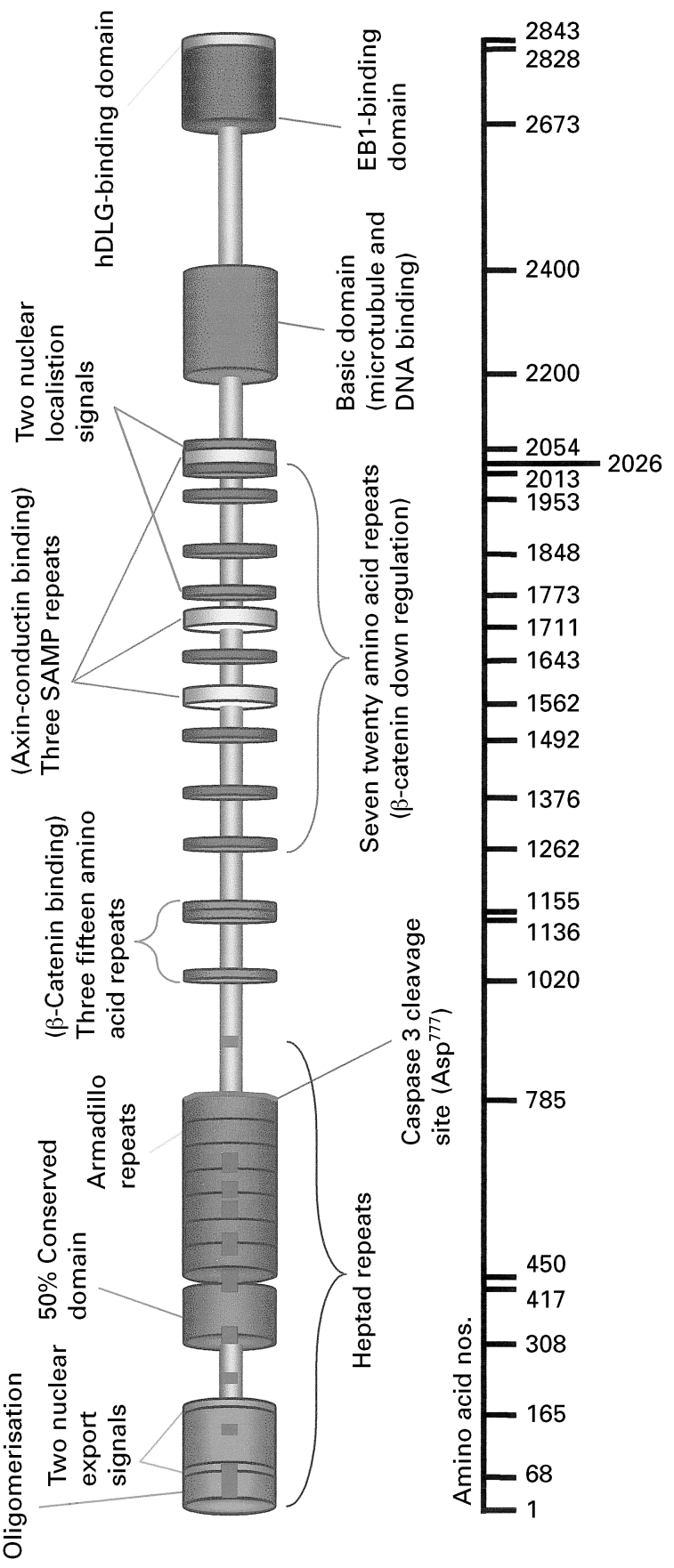

Fig. 2. Structural and functional domains of the adenomatous polyposis coli protein. The boundaries of longer domains and the start of shorter domains are indicated in amino acids shown below the protein structure. SAMP, Ser-Ala-Met-Pro; EB1, end-binding protein-1; hDLG, human homologue of discs large protein.

When $\beta$-catenin accumulates in the cytoplasm, it forms a complex with the transcription factor LEF-1 (Tcf-4), translocates to the nucleus and activates transcription of target genes (Behrens et al. 1996). However, APC proteins are involved in regulating many other aspects of cell function (Table 1).

Over-expression of $A P C$ inhibits cell proliferation (Baeg et al. 1995) through cell arrest in $\mathrm{G}_{0}$ or $\mathrm{G}_{1}$ (Groden et al. 


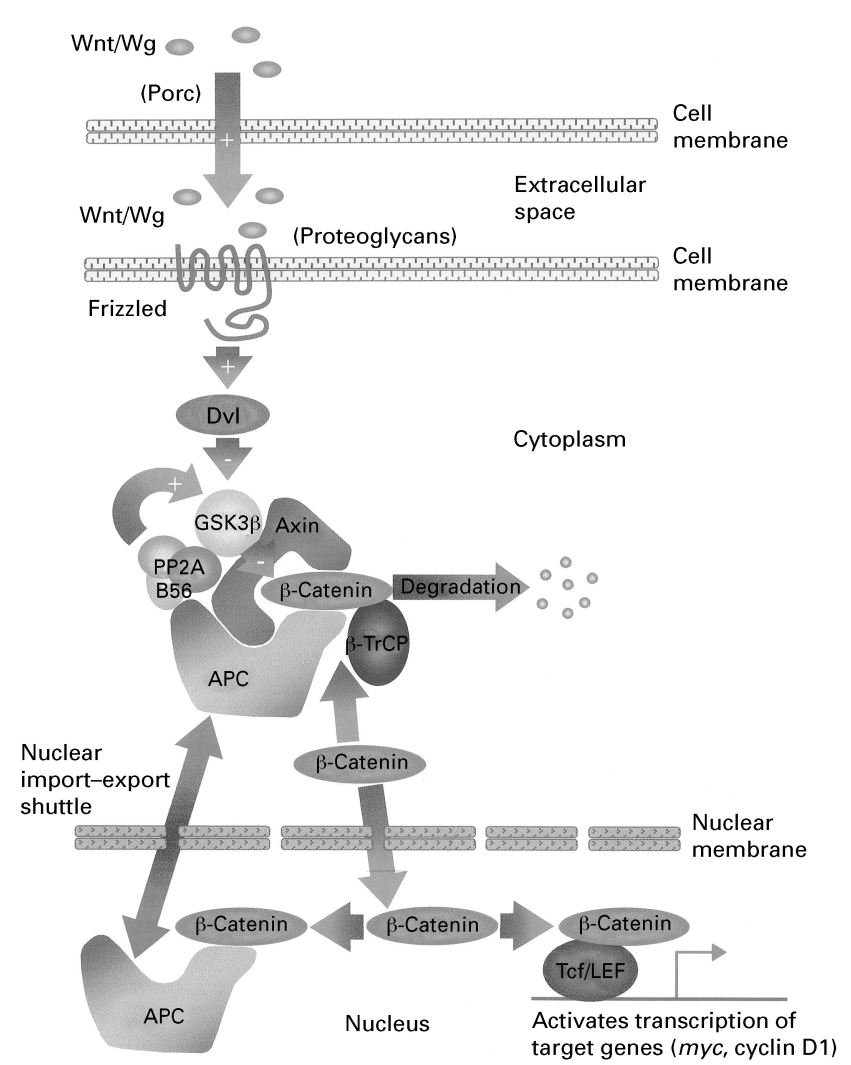

Fig. 3. Overview of the Wnt signalling pathway. Proteins shown include: Porc (Porcupine), Wnt/Wg (Wingless), Dvl (Dishevelled), GSK3 3 (glycogen synthase $3 \beta$ ) and PP2A (protein phosphatase 2A). APC, adenomatous polyposis coli; Tcf/LEF, T cell factor/lymphocyte enhancing factor; $\beta$-TrCP, $\beta$-transducin repeat-containing protein

Table 1. Putative functions of the adenomatous polyposis coli protein

1. Down regulation of $\beta$-catenin

2. Regulation of cell proliferation, differentiation and apoptosis

3. Regulation of cell-cell adhesion and of cell migration

4. Maintenance of chromosomal stability during mitosis

5. Regulation of the crypt fission cycle

1995), probably as a result of direct inhibition of cyclindependent kinases (Trzepacz et al. 1997). A lower level of apoptosis was observed in the macroscopically-normal colonic mucosa of patients with FAP compared with normal controls (Bedi et al. 1995), suggesting that the loss of even one allele of the $A P C$ gene reduces apoptosis. Direct evidence in support of the idea that APC is important in the induction or regulation of apoptosis comes from studies in which $A P C$ has been transfected into cell lines that do not express full-length APC protein, including SW480 and DLD-1 (Groden et al. 1995) and HT-29 (Morin et al. 1996). In the latter studies the transfected $A P C$ gene was placed under the control of a $\mathrm{Zn}$-inducible promoter so that, after establishing stable transfectants, the effect of APC expression could be investigated by exposure of the cells to high $\mathrm{Zn}$ concentrations. APC expression was accompanied by a suppression of cell growth and a dramatic increase in the numbers of floating cells, apoptotic cells that had detached from the surface of the culture vessels (Morin et al. 1996). In the normal colonic mucosal crypt APC is expressed in post-replicative cells towards the lumen surface (Midgley et al. 1997), where it may play a role in initiating apoptosis, possibly through release from the extracellular matrix or breakdown of cell-cell contacts (Fearnhead et al. 2001).

APC plays an important role in chromosomal stability through its binding with end-binding proteins (EB1), which are ubiquitous microtubule-associated proteins involved in microtubule search and capture, cell polarity and chromosome stability (Rehberg \& Graf, 2002). EB1 colocalises with APC (via the EB1-binding domain at the carboxy terminus of the protein; Fig. 2) to the spindle fibres and adjacent to the kinetochores during mitosis so that the EB1-APC complexes at the kinetochores form a physical link between the end of the spindle fibres and the centromeres of chromosomes (Fodde et al. 2001a). APC is found in many subcellular compartments, including the nucleus, to where it is directed by classical nuclear localisation signals (Zhang et al. 2000). Whilst in the nucleus, APC collects $\beta$-catenin and shuttles it out into the cytoplasm for degradation (Neufeld et al. 2000), a process aided by the nuclear export domains close to the $\mathrm{NH}_{2}$ terminus of the APC protein (Henderson, 2000).

Given the multiple and apparently disparate cellular functions of APC it remains a major challenge to determine whether APC proteins have a single molecular function that can explain the various biological effects of this fascinating protein (Bienz, 2002).

\section{Adenomatous polyposis coli gene and colo-rectal tumorigenesis}

Mutations in the APC gene occur in the majority of colorectal neoplastic lesions, with no difference in the frequency of mutations from the smallest benign adenomas to carcinomas, suggesting that $A P C$ mutations play a major role in the early development of CRC (Powell et al. 1992). Support for the idea that $A P C$ is a tumour suppressor gene comes from studies of $A P C$ mutations in tumours from patients with FAP and from Min mice (which carry a germ-line mutation at codon 850 in one allele of the $A p c$ gene) in which inactivating mutations were detected in the majority of human tumours (nineteen of twenty-four) and in all Min tumours (Levy et al. 1994). Loss of the second Apc allele could be detected in lesions containing as few as two dysplastic crypts (Levy et al. 1994), which confirms Knudson's two-hit hypothesis about the molecular function of tumour suppressor genes (see Strachan \& Read, 1999). Somatic mutations in the $A P C$ gene in colo-rectal tumours are found primarily in the proximal half of the gene, with a preponderance in the so-called mutation cluster region ranging from codons 1250-1550 (Fearnhead et al. 2001; see Fig. 1). Mutations in this region are believed to be tumorigenic because they prevent $\beta$-catenin down regulation and result in the expression of: oncogenes such as $c-m y c$ (He et al. 1998), which give the initiated cell a selective advantage; cyclin D1; the multidrug resistance 1 gene, which may initiate tumorigenesis by suppressing cell death 
pathways in colonocytes (Yamada et al. 2000); the dominant negative helix-loop-helix regulator Id2 (Rockman et al. 2001). Loss of function of $A P C$ can also occur through gene inactivation or silencing as a result of hypermethylation of the promoter region of the gene. This hypermethylation occurs in about $18 \%$ of the sporadic CRC in both adenomas and carcinomas and appears to be an early event in tumorigenesis (Esteller et al. 2000). In summary, $A P C$ is the gatekeeper gene for the colonic epithelium (Fodde et al. 1999), and loss of function of both APC alleles underlies both initiation and promotion of CRC (Fodde et al. $2001 b)$

\section{Genetically-targeted intervention studies in colo-rectal prevention}

\section{The Concerted Action Polyp Prevention 1 Study}

With the identification of germline mutations (such as those in $A P C$ causing FAP), which predispose to $\mathrm{CRC}$, it has become possible to design intervention studies to investigate the efficacy of potential chemo-prevention agents using carriers of the mutated gene as subjects. The benefits of such genetically-targeted interventions include: confidence that the genetic basis of the disease is known; shorter time frames because subjects with FAP are on a fast-track to CRC; a smaller number of subjects than would be needed with studies using healthy volunteers (since only a small proportion of the latter will develop gastrointestinal neoplasia); potential recruits are known to the clinical genetics teams; expectation of better compliance (families with FAP are strongly motivated to help with such research because the direct benefit to them is potentially large).

However, when such studies were being planned about a decade ago, other researchers argued that the genetic predisposition in FAP was so strong that the effects of dietary or pharmaceutical agents would be, at best, difficult to detect. Subsequent studies have shown that non-steroidal anti-inflammatory drugs, such as sulindac (Giardiello, 1994; Debinski et al. 1995) and the cyclooxygenase-2 selective inhibitor celecoxib (Steinbach et al. 2000), can suppress polyp development in subjects with FAP. Indeed, there is recent evidence that celecoxib may also help suppress duodenal polyposis in FAP (Phillips et al. 2002), a condition that is much more difficult to manage clinically than is colonic polyposis. In addition, there is now a wealth of evidence from mouse models carrying $A p c$ mutations that it is possible to manipulate tumour multiplicity by both pharmaceutical (Beazer-Barclay et al. 1996; Barnes \& Lee, 1998; MacGregor et al. 2000) and dietary agents (Kennedy et al. 1996; Wasan et al. 1997; Williamson et al. 1999). There is also growing evidence that other environmental factors such as bacterial infection can modify the severity of colonic neoplasia in Min mice (Newman et al. 2001).

The Concerted Action Polyp Prevention 1 Study was designed to recruit 400 mutant $A P C$ gene carriers with intact colons who were randomised to one of four treatments: (1) double placebo; (2) aspirin $(600 \mathrm{mg} / \mathrm{d})$; (3) resistant starch (30 g raw potato starch-Hylon VII $(1: 1, \mathrm{w} / \mathrm{w}) / \mathrm{d}) ;(4)$ aspirin and resistant starch. These intervention agents were chosen because (1) they were considered to be safe for prolonged use in healthy subjects (very important in a chemo-prevention study); (2) there was epidemiological and experimental evidence of potential efficacy (for overview, see Burn et al. 1998); (3) a putative mechanism of action for each agent was known. The anti-neoplastic actions of aspirin seem to be due mainly to its cyclooxygenaseinhibitory properties, which result in suppression of tumour cell growth, enhanced apoptosis and inhibition of angiogenesis (Elder \& Paraskeva, 1997; Sunayama et al. 2002). It is probable that resistant starch functions as a pro-drug, delivering the active agent butyrate by bacterial degradation of the polysaccharide in the colon (Mathers et al. 1997). There is extensive evidence that, at physiological concentrations, butyrate suppresses proliferation and increases apoptosis of CRC cells (Hague et al. 1993; Chai et al. 2000).

Each recruit to the study participated in the intervention for a minimum of 1 year, with endoscopic examination of the large bowel before intervention and annually thereafter. The primary outcome measure was the number of adenomatous polyps, and biopsies of the macroscopically-normal rectal mucosa were taken for investigation of putative biomarkers of CRC risk, including cell proliferation, apoptosis and crypt fission. Currently, analysis of both primary and secondary outcome data is underway.

\section{Acknowledgements}

The CAPP1 Study was funded by the European Union Biomed Programme, by the Imperial Cancer Research Fund (now Cancer Research UK) and by the Medical Research Council. I.M. thanks the BBSRC for a postgraduate studentship.

\section{References}

Asano T \& McLeod RS (2002) Dietary fibre for the prevention of colorectal adenomas and carcinomas (Cochrane Review). Cochrane Database Systematic Reviews CD003430. Oxford: The Cochrane Library.

Baeg GH, Matsumine A, Kuroda T, Bhattacharjee RN, Miyashiro I, Toyoshima K \& Akiyama T (1995) The tumor-suppressor gene product APC blocks cell-cycle progression from G0/G1 to S-phase. EMBO Journal 14, 5618-5625.

Barnes CJ \& Lee M (1998) Chemoprevention of spontaneous intestinal adenomas in the adenomatous polyposis coli Min mouse model with aspirin. Gastroenterology 114, 873-877.

Beazer-Barclay Y, Levy DB, Moser AR, Dove WF, Hamilton SR, Vogelstein B \& Kinzler KW (1996) Sulindac suppresses tumorigenesis in the Min mouse. Carcinogenesis 17, 1757-1760.

Bedi A, Pasricha PJ, Akhtar AJ, Barber JP, Bedi GC, Giardello FM, Zehnbauer BA, Hamilton SR \& Jones RJ (1995) Inhibition of apoptosis during development of colorectal-cancer. Cancer Research 55, 1811-1816.

Behrens J, Vonkries JP, Kuhl M, Bruhn L, Wedlich D, Grosschedl R \& Birchmeir W (1996) Functional interaction of $\beta$-catenin with the transcription factor Lef-1. Nature 382, 638-642.

Bienz M (2002) The subcellular destinations of APC proteins. Nature Reviews Molecular Cell Biology 3, 328-338.

Burn J, Chapman PD, Bishop DT \& Mathers J (1998) Diet and cancer prevention: the Concerted Action Polyp Prevention (CAPP) Studies. Proceedings of the Nutrition Society 57, 183-186. 
Burn J, Chapman PD, Bishop DT, Smalley S, Mickleburgh I, West S \& Mathers JC (2001) Susceptibility markers in colorectal cancer. In Biomarkers in Cancer Chemoprevention, pp. 131-147 [AB Miller, H Bartsch, P Boffetta, L Dragsted and H Vanio, editors]. Lyon, France: International Agency for Research on Cancer.

Chai F, Evdokiou A, Young GP \& Zalewski PD (2000) Involvement of $\mathrm{p} 21$ (Waf1/Cip1) and its cleavage by DEVDcaspase during apoptosis of colorectal cancer cells induced by butyrate. Carcinogenesis 21, 7-14.

Debinski HS, Trojan J, Nugent KP, Spigelman AD \& Phillips RK (1995) Effect of sulindac on small polyps in familial adenomatous polyposis. Lancet 345, 855-856.

Department of Health (1998) Nutritional Aspects of the Development of Cancer. Report on Health and Social Subjects no. 48. London: The Stationery Office.

Elder DJE \& Paraskeva C (1997) NSAIDs to prevent colorectal cancer: A question of sensitivity. Gastroenterology 113, 1999-2008.

Esteller M, Sparks A, Toyota M, Sanchez-Cespedes M, Capella G, Peinado MA, Gonzalez S, Tarafa G, Sidransky D, Meltzer SJ, Baylin SB \& Herman JG (2000) Analysis of adenomatous polyposis coli promoter hypermethylation in human cancer. Cancer Research 60, 4366-4371.

Fearnhead NS, Britton MP \& Bodmer WF (2001) The ABC of APC. Human Molecular Genetics 10, 721-733.

Fodde R, Kuipers J, Rosenberg C, Smits R, Kielman M, Gaspar C, van Es JH, Bruekel C, Weigant J, Giles RH \& Cleavers $\mathrm{H}$ (2001a) Mutations of the APC tumour suppressor gene cause chromosomal instability. Nature Cell Biology 3, 433-438.

Fodde R, Smits R \& Clevers H (2001b) APC, signal transduction and genetic instability in colorectal cancer. Nature Reviews Cancer 1, 55-67.

Fodde R, Smits R, Hofland N, Kielman M \& Meera Khan P (1999) Mechanisms of APC-driven tumorigenesis. Cytogenetics and Cell Genetics 86, 105-111.

Giardiello FM (1994) Sulindac and polyp regression. Cancer Metastasis Review 13, 279-283.

Groden J, Joslyn G, Samowitz W, Jones D, Bhattacharyya N, Spirio L, Thliveris A, Robertson M, Egan S, Meuth M \& White R (1995) Response of colon-cancer cell-lines to the introduction of $A P C$, a colon-specific tumor-suppressor gene. Cancer Research 55, 1531-1539.

Groden J, Thliveris A, Samowitz W, Carlson M, Gelbert L, Albertsen H, Joslyn G, Stevens J, Spirio L, Robertson M, Sarheant L, Krapcho K, Wolff E, Burt R, Hughes JP, Warrington J, McPherson J, Wasmuth J, Lepaslier D, Abderrahim H, Cohen D, Leppert M \& White R (1991) Identification and characterisation of the familial adenomatous polyposis-coli gene. Cell $\mathbf{6 6}$, 589-600.

Hague A, Manning AM, Hanlon KA, Huschtscha LI, Hart D \& Paraskeva C (1993) Sodium butyrate induces apoptosis in human colonic tumour cell lines in a p53-independent pathway: implications for the possible role of dietary fibre in the prevention of large-bowel cancer. International Journal of Cancer 55, 498-505.

Hanahan D \& Weinberg RA (2000) The hallmarks of cancer. Cell 100, 57-70.

He TC, Sparks AB, Rago C, Hermeking H, Zawel L, da Costa LT, Morin PJ, Vogelstein B \& Kinzler KW (1998) Identification of c-MYC as a target of the APC pathway. Science 281, $1438-1441$.

Henderson BR (2000) Nuclear-cytoplasmic shuttling of APC regulates beta-catenin subcellular localisation and turnover. Nature Cell Biology 2, 653-660.

Horii A, Nakatsuru S, Ichii S, Nagase H \& Nakamura Y (1993) Multiple forms of the Apc gene transcripts and their tissue-specific expression. Human Molecular Genetics 2 283-287.

Kennedy AR, Beazer-Barclay Y, Kinzler KW \& Newberne PM (1996) Suppression of carcinogenesis in the intestines of Min mice by soybean-derived Bowman-Birk inhibitor. Cancer Research 56, 679-682.

Kinzler KW, Nilbert MC, Su LK, Vogelstein B, Bryan TM, Levy DB, Smith KJ, Preisinger AC, Hedge P, McKechnie D, Finniear R, Markham A, Groffen J, Boguski MS, Altshul SF, Horii A, Ando H, Miyoshi Y, Miki Y, Nishisho I \& Nakamura Y (1991) Identification of FAP locus genes from chromosome 5q21. Science 253, 661-665.

Kishida S, Yamamoto H, Ikeda S, Kishida M, Sakamoto I, Koyama S \& Kikuchi A (1998) Communication - Axin, a negative regulator of the Wnt signalling pathway, directly interacts with adenomatous polyposis coli and regulates stabilization of $\beta$-catenin. Journal of Biological Chemistry 273, $10823-10826$.

Klingensmith J \& Nusse R (1994) Signalling by Wingless in Drosophila. Developmental Biology 166, 396-414.

Levy DB, Smith KJ, Beazer-Barclay Y, Hamilton SR, Vogelstein B \& Kinzler KW (1994) Inactivation of both APC alleles in human and mouse tumors. Cancer Research 54, 5953-5958.

MacGregor D, Kim YS, Sleisenger MH \& Johnson LK (2000) Chemoprevention of colon cancer carcinogenesis by balsalazide: Inhibition of azoxymethane-induced aberrant crypt formation in the rat colon and intestinal tumor formation in the B6-Min/ + mouse. International Journal of Oncology 17, 173-179.

Mathers JC, Smith H \& Carter S (1997) Dose-response effects of raw potato starch on small-intestinal escape, large bowel fermentation and gut transit time in the rat. British Journal of Nutrition 78, 1015-1029.

Midgley CA, White S, Howitt R, Save V, Dunlop MG, Hall PA, Lane DP, Wyllie AH \& Bubb VJ (1997) APC expression in normal human tissues. Journal of Pathology 181, 426-433.

Morin PJ, Vogelstein B \& Kinzler KW (1996) Apoptosis and APC in colorectal tumorigenesis. Proceedings of the National Academy of Sciences USA 93, 7950-7954.

Nakagawa H, Murata Y, Koyama K, Fujiyama A, Miyoshi Y, Monden M, Akiyama T \& Nakamura Y (1998) Identification of a brain-specific $A P C$ homologue, $A P C L$, and its interaction with $\beta$-catenin. Cancer Research 58, 5176-5181.

Neufeld KL, Zhang F, Cullen BR \& White RL (2000) APCmediated downregulation of beta-catenin activity involves nuclear sequestration and nuclear export. EMBO Reports 1, $519-523$.

Newman JV, Kosaka T, Sheppard BJ, Fox JG \& Schauer DB (2001) Bacterial infection promotes colon tumorigenesis in $\mathrm{Apc} \mathrm{Min} /+$ mice. Journal of Infectious Diseases 184, 227-230.

Phillips RK, Wallace MH, Lynch PM, HawkE, Gordon GB, Saunders BP, Wakabayaski N, Shen Y, Zimmerman S, Godio L, RodriguesBigas M, Su LK, Sherman J, Kelloff G, Levin B, Steinbach G \& FAP Study Group (2002) A randomised, double blind, placebo controlled study of celecoxib, a selective cyclooxygenase inhibitor, on duodenal polyposis in familial adenomatous polyposis. Gut 50, 857-860.

Powell SM, Zilz N, Beazer-Barclay Y, Bryan TM, Hamilton SR, Thibodeau SN, Vogelstein B \& Kinzler KW (1992) Apc mutations occur early during colorectal tumorigenesis. Nature 359, 235-237.

Pyles RB, Santoro IM, Groden J \& Parysek LM (1998) Novel protein isoforms of the APC tumour suppressor in neural tissue. Oncogene 16, 77-82.

Rehberg M \& Graf R (2002) Dictyostelium EB1 is a genuine centrosomal component required for proper spindle formation. Molecular Biology of the Cell 13, 2301-2310. 
Rockman SP, Currie SA, Ciavarella M, Vincan E, Dow C, Thomas RJ \& Phillips WA (2001) Id2 is a target of the betacatenin/T cell factor pathway in colon carcinoma. Journal of Biological Chemistry 276, 45113-45119.

Rubinfeld B, Albert I, Porfiri E, Munemitsu S \& Polakis P (1997) Loss of $\beta$-catenin regulation by the APC tumor suppressor protein correlates with the loss of structure due to common somatic mutations of the gene. Cancer Research 57, 4624-4630.

Santoro IM \& Groden J (1997) Alternative splicing of the APC gene and its association with terminal differentiation. Cancer Research 57, 488-494.

Schatzkin A, Lanza E, Corle D, Lance P, Shike M, Weissfeld J, Burt R, Cooper MR, Kikendall JW \& Cahill J (2000) Lack of effect of a low-fat, high-fiber diet on the recurrence of colorectal adenomas. Polyp Prevention Trial Study Group. New England Journal of Medicine 342, 1149-1155.

Steinbach G, Lynch PM, Phillips RK, Wallace MH, Hawk E, Gordon GB, Wakabayashi N, Saunders B, Shen Y, Fujimura T, Su LK \& Levin B (2000) The effect of celecoxib, a cyclooxygenase-2 inhibitor, in familial adenomatous polyposis. New England Journal of Medicine 342, 1946-1952.

Strachan T \& Read (1999) Human Molecular Genetics 2, pp. 435-436. Oxford: BIOS Scientific Publishers Ltd.

Su LK, Vogelstein B \& Kinzler KW (1993) Association of the Apc tumor-suppressor with catenins. Science 262, 1734-1737.

Sulekova Z \& Ballhausen WG (1995) A novel coding exon of the human adenomatous polyposis-coli gene. Human Genetics 96, 469-471.

Sunayama K, Konno H, Kakamura T, Kashiwabara H, Shoji T, Tsuneyoshi T \& Nakamura S (2002) The role of cyclo- oxygenase-2 (COX-2) in two different morphological stages of intestinal polyps in $\mathrm{APC}^{\Delta 474}$ knockout mice. Carcinogenesis 23, $1351-1359$

Thliveris A, Albertsen H, Tuohy T, Carlson M, Groden J, Joslyn G, Gelbert L, Samowitz W, Spirio L \& White R (1996) Long-range physical map and deletion characterization of the 1100-kb Not1 restriction fragment harboring the APC gene. Genomics 34, 268-270.

Trzepacz C, Lowy AM, Kordich JJ \& Groden J (1997) Phosphorylation of the tumor suppressor adenomatous polyposis coli (APC) by the cyclin-dependent kinase p34 (cdc2). Journal of Biological Chemistry 272, 21681-21684.

Wasan H, Novelli M, Bee J \& Bodmer WF (1997) Dietary fat influences on polyp phenotype in multiple intestinal neoplasia mice. Proceedings of the National Academy of Sciences USA 94, 3308-3313.

Williamson SLH, Kartheuser A, Coaker J, Kooshkghazi MD, Fodde R, Burn J \& Mathers JC (1999) Intestinal tumorigenesis in the Apc1638N mouse treated with aspirin and resistant starch for up to 5 months. Carcinogenesis 20, 805-810.

Yamada T, Takaoka AS, Naishiro Y, Hayashi R, Maruyama K, Maesawa C, Ochiai A \& Hirohashi S (2000) Transactivation of the multidrug resistance 1 gene by T-cell factor 4/beta-catenin complex in early colorectal carcinogenesis. Cancer Research 60, 4761-4766.

Zhang F, White RL \& Neufeld KL (2000) Phosphorylation near nuclear localisation signal regulates nuclear import of adenomatous polyposis coli protein. Proceedings of the National Academy of Sciences USA 97, 12577-12582. 